\title{
From South Africa to Sri Lanka: Prospects of Travel for 'Transformative Constitutionalism,
}

\author{
Dinesha SAMARARATNE* \\ University of Melbourne, Australia \\ University of Colombo, Sri Lanka \\ d.samararatne@unimelb.edu.au
}

\begin{abstract}
What lessons can we learn from the way in which the South African experience of transformative constitutionalism was invoked in Sri Lanka's recent constitutional reform experience? What conditions allow experiences of transformative constitutionalism to travel? In this article, I respond to these two questions, using Frankenberg's idea of a 'layered approach' in comparative constitutional law. My analysis affirms that in the comparative enterprise, a thick explanation that allows each experience to 'speak for itself' heightens the value of a comparative example. In the case of South Africa, I demonstrate that transformative constitutionalism is in fact a specific genre of constitutionalism. It demands attention not only to substantive constitutional guarantees and institutional design, but also to the process of constitutional reform. Moreover, effective measures for transitional justice are an essential component of transformative constitutionalism. A closer reading of South African experience that paid attention to these factors would have led to better use of this experience in Sri Lanka's post-war constitutional governance.
\end{abstract}

What can we learn from the use of the South African experience in the constitutional governance and reform experiment by 'constitutional legislators' in post-war Sri Lanka (20092019)?. ${ }^{1}$ In seeking answers to this question, I engage with three debates in the field of comparative constitutional law. The first is the debate on methodology in comparative constitutional law. The methodology debate, in the context of constitution-making, is at a very early stage in the field of comparative constitutional law. The second is the debate on the character of 'transformative constitutionalism'. This term is primarily associated with the South African experience of becoming a constitutional democracy. Transformative constitutionalism is viewed by some as an approach to constitutional governance that is new and different to that of liberal constitutionalism. The literature on transformative constitutionalism is preoccupied with the work of the Constitutional Court of South Africa. I argue that transformative constitutionalism is better understood as a genre of constitutionalism

* LLB (Hons)(Colombo), LLM (Harvard), PhD (Colombo), Attorney-at-Law (Sri Lanka). Postdoctoral Fellow, ARC Laureate Program in Comparative Constitutional Law, Melbourne Law School; concurrently Senior Lecturer, Department of Public \& International Law, Faculty of Law, University of Colombo. A draft of this paper was presented at the 'Public Law in Four Nations' conference convened by the Faculty of Law, University of Witwatersrand, South Africa on 2-5 July 2019. I thank Toerien Van Wyk, PhD candidate, Melbourne Law School, for her comments on this paper, and the Academic Research Service at the Melbourne Law School for their research support. Research for this paper was undertaken from April to August 2019 and was fully funded by the Australian Government through the Australian Research Council (ARC) Laureate Program 'Balancing Diversity and Social Cohesion in Democratic Constitutions'.

1 On the usage of the term 'constitutional legislators' see Vicki C Jackson, 'Comparative Constitutional Law: Methodologies', in Michel Rosenfeld \& Andras Sajo (eds), The Oxford Handbook of Comparative Constitutional Law (Oxford University Press 2012) 69. 
that is enabled by a range of conditions, among which an independent and strong Constitutional Court is but one. The third debate that I intervene in is the discussion on the manner and form of constitutional reform in Sri Lanka. I argue that any attempt to emulate South Africa's experience of 'transformative constitutionalism' in Sri Lanka's reform experiment requires greater attention to (a) the broader political, social, and economic context; and (b) the closely inter-connected processes by which constitutional reform was carried out in South Africa. I argue further that, in Sri Lanka, the South African experiences were used piecemeal within a constitutional reform project that was not intended to result in a fundamental transformation of the existing character of the constitution. The selective overlay of certain aspects of South Africa's transformative constitutionalism were therefore less likely to have a 'transformative impact'.

This article is organised in five parts. In Part I, I begin by highlighting the gap in the debate on methodology in comparative constitutional law regarding constitution-making. This is followed by a critical assessment of 'transformative constitutionalism' in Part II, where I argue that it ought to be understood as a specific genre of constitutionalism. In Part III, I assess the recent constitutional reform experiment in Sri Lanka, and in Part IV, I evaluate the ways in which the South African experiences were invoked in that process. I examine three specific aspects of the Sri Lankan reform exercise in this Part: the process of constitutional reform, public consultation, and some of the substantive proposals. In Part V, I present my case for a methodology that insists on a sharper focus on the political, social, economic, and legal specificities within the comparative enterprise, particularly in relation to constitution-making.

\section{DILEMMAS OF COMPARATIVE METHODS FOR CONSTITUTION-MAKING}

What is the relevance of South Africa's constitution-making experience to Sri Lanka's constitutional reform project? How should constitutional legislators decide on the specific examples that they will follow or be inspired by in deciding upon the manner and form of constitutional reform in Sri Lanka? These questions draw attention to some of the grey areas in the use of comparative experiences in constitutional governance in Sri Lanka. The debate on methodology in comparative constitutional law has responded to similar questions, but mostly in relation to why and how judges use or refer to foreign law in their judgments. The debate is yet to be extended in a coherent way to other sub-fields of comparative constitutional law such as constitution-making. Even the existing debate, as Tushnet reminds us, reveals that one 'should be appropriately cautious about what they believe they can learn from the study of comparative constitutional law.'.

The significant interventions in the methodological debates in comparative constitutional law have been mapped in a useful way by Vicki Jackson. As Jackson suggests, the 'comparative enterprise' is wide-ranging and includes 'doctrine produced by courts, features of government, and the processes of constitution-making and adoption. ' 3 Each of these

2 Mark Tushnet, 'Some reflections on method in comparative constitutional law', in Sujit Choudhry (ed), The Migration of Constitutional Ideas (Cambridge University Press 2006) 83.

Jackson (n 1) 54. 
subsets of activities is associated with a range of methodological challenges. One of these challenges is the need for an inter-disciplinary approach in making the comparison. For instance, Ran Hirschl argues that 'any attempt to portray the constitutional domain as ... predominantly legal, rather than imbued in the social or political arena, is destined to yield thin, ahistorical, overly doctrinal, or formalistic accounts of the origins, nature and consequences of constitutional law.' ${ }^{4}$ Hirschl describes current methodologies of comparative constitutional law as 'fuzzy and amorphous at best.' 5 A turn to the social sciences and to its 'tremendous descriptive depth and explanatory potential' is essential, according to Hirschl, if the study of comparative constitutional law is to be linked to its 'actual capacity to induce real change.' 6 Saunders cautions against the marginalization and/or the homogenization of the constitutional experiences of states and regions in this field. She calls for comparative constitutional law to be understood as 'a global constitutional gene pool'. ${ }^{7}$ She identifies a range of challenges posed by diversity and particularity to comparative constitutional law, including the challenges posed by culture and pluralism in different jurisdictions.

Tushnet's intervention in this debate is to categorise existing methodologies into three: normative universalism, functionalism, and contextualism. He identifies two subsets of contextualism - simple contextualism and expressivism. Normative universalism presupposes that constitutional ideas have a universal reach. Functionalism focuses on the outcomes that are sought to be achieved through constitutional ideas. Contextualism insists that 'constitutional ideas can only be understood in the full institutional and doctrinal context within which they are placed'. ${ }^{8}$ Expressivism, as a sub-set of contextualism, 'takes constitutional ideas to be expressions of a particular nation's self-understanding.' '?

These academic interventions on methodology in comparative constitutional law are helpful in identifying the limitations of current approaches to research in the field. The approach is mainly of diagnosis rather than prescription. The development of prescriptive approaches would be useful for the development of more robust theory in this field. It would help to avoid what Hirschl described as a 'an asystematic and methodology-light practice of research design and case selection. ${ }^{10}$

Frankenberg offers an even stronger critique of comparative method.. ${ }^{11} \mathrm{He}$ calls for what he describes as a 'post-Cinderella and post-Sleeping Beauty mode of comparative constitutional studies.' ${ }^{12}$ He defends 'a layered approach' to comparative constitutional law that focuses on specificities. The layered approach emphasizes that a constitution has several

\footnotetext{
Ran Hirschl, 'Editorial' (2013) 11 International Journal of Constitutional Law 1, 2.

ibid 9.

ibid 7.

Cheryl Saunders, 'Towards a Global Constitutional Gene Pool' (2009) 4 National Taiwan University Law Review 3.

8 Tushnet (n 2) 68.

10 Ran Hirschl, 'On the blurred methodological matrix of comparative constitutional law', in Sujit Choudhry (ed), The Migration of Constitutional Ideas (Cambridge University Press 2006) 66.

11 See Gunter Frankenberg, 'Comparing constitutions: Ideas, ideals, and ideology - toward a layered narrative' (2006) 4 International Journal of Constitutional Law 439.

12 ibid 459. The reference to Cinderella is a way of highlighting the neglect of the debate on method in comparative law. The reference to Sleeping Beauty is a way of highlighting the increased attention to, and interest in, comparative method.
}

9 ibid. 
layers of meanings, including the following - constitutions as law and order, constitutions as culture (and mutually constituting with culture), and constitutions as the imagination of the community. ${ }^{13}$ To Frankenberg, an appreciation for the layered and inter-related functions of a constitution ought to be central to the comparative enterprise in constitutional law. ${ }^{14}$

In this article, I attempt a modest and specific contribution to this debate. Through my critique of the invocation of South Africa's experience in transformative constitutionalism in constitutional reform and governance in Sri Lanka, I propose ways of thinking about methodology (particularly in relation to constitution-making) within the broader field of methodology in comparative constitutional law. I draw upon Frankenberg's idea of a 'layered approach' in this task. I develop this analysis in the next Part by offering a contextualised assessment of transformative constitutions using 'the layered approach'.

\section{TRANSFORMATIVE CONSTITUTIONALISM}

The literature on transformative constitutionalism presents it as a genre of constitutionalism that is distinct from 'liberal democratic constitutionalism'. ${ }^{15}$ Transformative constitutionalism, according to Klare, is about the possibility of achieving 'dramatic social change through lawgrounded processes.' ${ }^{16}$ This social change, according to Klare, is a 'transformation vast enough to be inadequately captured by the phrase "reform", but is something short of or different from "revolution".. ${ }^{17}$ Klare famously described transformative constitutionalism as:

...a long-term project of constitutional enactment, interpretation, and enforcement (not in isolation, of course, but in a historical context of conducive political developments) to transforming a country's political and social institutions and power relationships in a democratic, participatory, and egalitarian direction. ${ }^{18}$

He identifies five aspects of the South African constitution that justify this particular interpretation. These aspects establish clearly that transformative constitutionalism is 'postliberal', in the sense that it is distinctive in manner and form from 'liberal constitutionalism'. For instance, Klare points to the 'historical self-consciousness' of the South African

13 ibid 443-451.

14 Also see, in this regard, Gunter Frankenberg, 'Critical Comparisons: Re-thinking Comparative Law' (1985) 26 Harvard Journal of International Law 411; Gunter Frankenberg, 'Comparative constitutional law', in Mauro Bussani and Ugo Mattei (eds), The Cambridge Companion to Comparative Constitutional Law (Cambridge University Press 2012) 171; Gunter Frankenberg, Comparative Law as Critique (Edward Elgar Publishing 2016).

15 For a critique of liberal constitutionalism see Mark Tushnet, 'The Dilemmas of Liberal Constitutionalism' (1981) 42 Ohio State Law Journal 411.

16 Karl E Klare, 'Legal Culture and Transformative Constitutionalism' (1998) 14 South African Journal on Human Rights 146, 150.

17 ibid.

18 ibid. Compare the South African approach to transformative constitutionalism with that of understandings of transformative constitutionalism as developed in Latin America. See eg Armin Von Bogdandy et al, Transformative Constitutionalism in Latin America: The Emergence of a New Ius Commune (Oxford University Press 2017). 
Constitution as 'an instrument committed to social transformation and reconstruction'.. ${ }^{19}$ Furthermore, it is emphasized that 'legal and political institutions are chosen, not given, that democracy must be periodically reinvented, and that the Constitution itself is the contingent (even fragile) product of human agency. ${ }^{20}$ Elsewhere, Klare identifies how legal culture is critical in this project. He notes that 'legal culture and socialization constrain legal outcomes quite irrespective of the substantive mandates entrenched in constitutions and legislation.' 21 Klare argues that transformative constitutionalism demands 'a new imagination and selfreflection' about legal methods and legal adjudication.. ${ }^{22}$ For Klare, while 'law and legal practices' can facilitate transformation, it requires 'an updated, politicized account of the rule of law.' ${ }^{23}$ According to this account, transformative constitutionalism is transformative of the entire legal system. This transformation is expected to be a mutually constitutive character of the legal, the political, and the social in society.

Subsequent debates on transformative constitutionalism, however, focus primarily on the work of the Constitutional Court of South Africa, its methods of reasoning, and the impact of its judgments on South African society. ${ }^{24}$ These debates have been extended to an assessment of how other courts have been inspired (or otherwise) by the South African example, and also to a more complex accounting for the origins and history of the concept of transformative constitutionalism. ${ }^{25}$ Not much attention has been devoted to other conditions and contingencies that Klare described as being critical to the project of transformative constitutionalism. Whether from a historical perspective or in terms of a better understanding of the potential and the limits of transformative constitutionalism, not much is understood within debates on transformative constitutionalism about the place of these other conditions and contingencies. ${ }^{26}$

Within the field of comparative constitutional law, it is not adequate to understand transformative constitutionalism only in terms of the methods employed by the South African Constitutional Court. Transformative constitutionalism ought to be appreciated as a specific genre of constitutionalism. This genre is, in my view, characterised by the following. It is a result of the political and social liberation movement against apartheid. It explicitly casts positive obligations on the state to ensure social justice. For the judicial branch of the state, this approach demands a specific mode of judicial reasoning, including a constitutional commitment to the positive duty to protect. ${ }^{27}$ For all actors within the legal sector, it means that all laws, modes of interpretation, and practice must be aligned with transformative

19 Klare (n 16) 155.

20 ibid.

21 ibid 151.

22 ibid 156.

23 ibid 188.

24 See eg Dikgang Moseneke, 'The Fourth Bram Fischer Memorial Lecture - Transformative Adjudication' (2002) 18 South African Journal on Human Rights 309; Stu Woolman, 'Understanding South Africa's Aspirational Constitution as Scaffolding' (2015) 60 New York Law School Law Review 283; Michaela Hailbronner, 'Transformative Constitutionalism: Not Only in the Global South' (2017) 65 American Journal of Comparative Law 527; Eric Kibet \& Charles Fombad, 'Transformative Constitutionalism and the Adjudication of Constitutional Rights in Africa' (2017) 17 African Human Rights Law Journal 340.

25 See eg Hailbronner (n 24).

26 For an account of these contingencies in the German context, see Dieter Grimm, Constitutionalism: Past, Present, and Future (Oxford University Press 2016).

27 That is to say, the constitutional obligation to enforce a positive right. 
constitutionalism. The legal culture is expected to engage in a continuous process of transformation. Other areas that are required to engage in this continuous transformation include legal education and the reconciliation process. ${ }^{28}$ Transformative constitutionalism has a stronger focus on the 'ought' than on the 'is'.

It must be noted at this point that transformative constitutionalism has been critiqued for its ambiguity as well. Fowkes, for instance, notes that ' $[\mathrm{t}]$ ransformative constitutionalism ... is about preservation as well as change, about restraint as well as boldness, about retaining things from an old order (at least temporarily) as well as sharply rejecting them. ${ }^{29}$ He goes on to note that 'transformative constitutionalism is the closest thing to an empty term, standing for change unless it does not and judicial boldness unless the situation calls for restraint. ${ }^{30} \mathrm{He}$ warns that it is 'a conceptual problem without a conceptual solution'.. 31

Contemporary South Africa is facing widening inequality and a high incidence of violence. ${ }^{32}$ This reality contrasts with the transformative promise of the South African Constitution. ${ }^{33}$ These conditions are a reminder that transformative constitutionalism, which provides the structure for transforming the legal culture, must also be accompanied by improvements in the actual quality of life in society. As Sibanda points out, the capacity of transformative constitutionalism to respond to these social and economic concerns will determine its continued relevance to South Africa's future. ${ }^{34}$ More recently, an attempt has been made to revisit transformative constitutionalism 'within the historical matrix of colonialism and Eurocentrism'. ${ }^{35}$ Through this approach, scholars are attempting to deepen their understanding of the prospects for South Africa's constitutional order.

Understanding transformative constitutionalism as a specific genre has the following implications. Firstly, constitutional design, institutions, and substantive provisions should be ascribed meanings that are coherent and consistent with the normative foundation of

28 Jason Brickhill \& Yana Van Leeve, 'Transformative Constitutionalism - Guiding Light or Empty Slogan' (2015) Acta Juridica 141.

29 James Fowkes, 'Transformative Constitutionalism and the Global South: The View from South Africa', in Von Bogdandy et al (n 18) 105.

30 ibid.

31 ibid 106. For a similar critique, see Francois Venter, 'The Limits of Transformation in South Africa's Constitutional Democracy' (2018) 34 South African Journal on Human Rights 143.

32 On inequality in South Africa, see eg Charles Simkins, 'Poverty, Inequality, and Democracy: South African Disparities' (2011) 22 Journal of Democracy 105; Fiona Tregenna \& Mfanafuthi Tsela, 'Inequality in South Africa: The distribution of income, expenditure and earnings' (2012) 29 Development Southern Africa 35. On violence in South Africa, see eg Anton du Plessis \& Antoinett Louw, 'Crime and Crime Prevention in South Africa: 10 Years After' [2005] Canadian Journal of Criminology \& Criminal Justice 427; Michael Neocosmos, 'The Politics of Fear and the Fear of Politics: Reflections on Xenophobic Violence in South Africa' (2008) 43 Journal of Asian and African Studies 586.

33 For a critique of the South African constitutional project, see Theunis Roux, 'Transformative Constitutionalism and the Best Interpretation of the South African Constitution: Distinction without a Difference?' (2009) 20 Stellenbosch Law Review 258.

34 Sanele Sibanda, 'Not Purpose-Made! Transformative Constitutionalism, Post-Independence Constitutionalism and the Struggle to Eradicate Poverty' (2011) 22 Stellenbosch Law Review 482. See also Mashele Rapatsa, 'Re-thinking the Constitution's Rights-based Approaches and Klare's Social Change Phenomenon: A View towards Securing Human Well-being and Societal Stability' (2017) 13 Acta Universitatis Danubius Juridica 65.

35 See in this regard Mogobe Bernard Ramose, 'Towards a Post-Conquest South Africa: Beyond the Constitution of 1996' (2018) 34 South African Journal on Human Rights 326; DM Davis, 'Is the South African Constitution an Obstacle to a Democratic Post-Colonial State?' (2018) 34 South African Journal on Human Rights 359. 
transformative constitutionalism. Secondly, the sequential place of constitutional text and implementation within this specific genre has to be recognised. The South African experience of transformative constitutionalism includes certain features which establish that constitutional reform and the enforcement of the constitution is in fact a result of particular political, cultural, and even economic processes. Thirdly, the poverty, inequality, and violence experienced in South Africa highlights the need to pay greater attention to the relationships between these realities and constitutional governance.

The foregoing implications suggest that a thicker account of transformative constitutionalism will strengthen the comparative enterprise. These implications also provide a convincing explanation as to why the comparative reliance on South Africa's version of transformative constitutionalism has failed to yield the expected outcomes. In the next Part, I illustrate one such instance in post-war Sri Lanka.

\section{CONSTITUTIONAL GOVERNANCE AND REFORM IN POST-WAR SRI LANKA}

The military defeat of the Liberation Tigers of Tamil Eelam (LTTE) in May 2009 is a milestone in Sri Lanka's contemporary history. It marks the end of a three decade-long internal armed conflict. ${ }^{36}$ Constitutional governance in the decade since then can be roughly divided into two stages, using the change of government in 2015 as a landmark. South Africa's transition to democratic governance was invoked mostly in relation to transitional justice in the first stage (from 2009 to 2014), and mostly in relation to constitution-making in the second stage (from 2015 to 2018).

\section{A. Constitutional Governance (2009-2014)}

Constitutional governance in the first stage (2009-2014) was shaped by two significant developments. One was the Eighteenth Amendment to the Constitution of the Democratic Socialist Republic of Sri Lanka 1978 (the 1978 Constitution). ${ }^{37}$ The other was the impeachment of the Chief Justice in January 2013. The Eighteenth Amendment effected two fundamental changes in the 1978 Constitution: it removed the two-term restriction on the office of the Executive President, and it replaced the Constitutional Council with a Parliamentary Council. The Constitutional Council had earlier been introduced by the Seventeenth Amendment in 2001. The Council comprised the Prime Minister, the Speaker of Parliament, the Leader of the Opposition, and seven individuals from civil society. ${ }^{38}$ It acted as a body vetting the power of

36 For an account of the internal armed conflict in Sri Lanka from a constitutional perspective, see Visakesa Chandrasekaram, The Use of Confessionary Evidence under the Counter-Terrorism Laws of Sri Lanka: An Interdisciplinary Study (Amsterdam University Press 2017) 17-31; Asanga Welikala, A State of Permanent Crisis: Constitutional Government, Fundamental Rights, and States of Emergency in Sri Lanka (Centre for Policy Alternatives 2008).

37 For a critical examination of the Eighteenth Amendment to the Constitution of the Democratic Socialist Republic of Sri Lanka (the 1978 Constitution), see Rohan Edrisinha and Aruni Jayakody (eds), The Eighteenth Amendment to the Constitution: Substance and Process (Centre for Policy Alternatives 2011).

38 Seventeenth Amendment to the 1978 Constitution, art 41A. Individuals from civil society were appointed as follows: one appointed by the President, five nominated by the Prime Minister and the Leader of the 
the Executive President to appoint individuals to high office and to independent commissions. ${ }^{39}$ In 2010, the Eighteenth Amendment replaced the Constitutional Council with a Parliamentary Council. The President only had to 'seek the observations' of this Council in making appointments to specified independent commissions and to specified high offices. ${ }^{40}$

The Eighteenth Amendment Bill, which effectively repealed the Seventeenth Amendment, was determined to be constitutional by the Supreme Court and was enacted with the required special majority support in Parliament.- ${ }^{41}$ This had the effect of weakening constitutionalism by enlarging the reach of the Executive Presidency.. ${ }^{42}$ This was evident in the manner in which the Chief Justice was impeached in January 2013. ${ }^{43}$ The impeachment was pursuant to a procedure that was flawed by design and partial in effect. ${ }^{44}$ The Sri Lankan Government was criticised locally and internationally for the impeachment. ${ }^{45}$

This weakening of constitutional governance was accompanied by a notable absence of policy measures to address the issues of justice for those affected by the internal armed conflict. During this time, sections of civil society maintained a national and international demand for transitional justice. That demand was often substantiated by references to South Africa's experiences in transitional justice. From May 2009 onwards, Sri Lanka increasingly came under the scrutiny of the Human Rights Council of the United Nations (UN) for its failure to implement measures for transitional justice. ${ }^{46}$ The reports commissioned by the UN Secretary-

Opposition and appointed by the President, and one nominated by political parties other than the parties that the Prime Minister and the Leader of the Opposition belong to.

39 The independent commissions are the Elections Commission, the Public Service Commission, the National Police Commission, the Human Rights Commission, the Commission to Investigate Allegations of Bribery and Corruption, the Finance Commission, and the Delimitation Commission: Seventeenth Amendment to the 1978 Constitution, Schedule to art 41B. The high offices are those of the Chief Justice and the judges of the Supreme Court, the President and the judges of the Court of Appeal, members of the Judicial Service Commission, the Attorney-General, the Auditor-General, the Inspector-General of Police, the Parliamentary Commissioner for Administration, and the Secretary-General of Parliament: Seventeenth Amendment to the 1978 Constitution, Schedule to art 41C.

40 Eighteenth Amendment to the 1978 Constitution, art 411A(1).

41 In re the Eighteenth Amendment Bill SC (SD) No 01/2010, SC Minutes 31st August 2010.

42 For a critical account of the Executive Presidency under the Sri Lankan Constitution, see Asanga Welikala (ed), Reforming Sri Lankan Presidentialism: Provenance, Problems and Prospects (Centre for Policy Alternatives 2015).

43 For an examination of the political and constitutional issues related to the impeachment of the Chief Justice, see International Bar Association, 'A Crisis of Legitimacy: The Impeachment of Chief Justice Bandaranayake and the Erosion of the Rule of Law in Sri Lanka' (Human Rights Institute, Executive Summary, Apr 2013) $<$ https://www.ibanet.org/Document/Default.aspx?DocumentUid=C6E5D350-64F5-419C-8161C281BA8EDFCF> accessed 2 Mar 2020.

44 The 1978 Constitution, art 107(3) provides that Parliament 'shall by law or by Standing Orders' provide for all matters relating to the impeachment of judges of the appellate courts. The procedure in place for impeachment has been established by way of a Standing Order. It provides that a Parliamentary Select Committee (PSC) should investigate and determine the allegations made against the judge in question. In the case of Chief Justice Bandaranayake, the government of the day followed this procedure; however, the Chief Justice was not afforded the guarantees of natural justice during the hearings before the PSC.

45 For instance, it was described as a 'threat to the independence of the justice system' by the United Nations Special Rapporteur on the independence of judges and lawyers, Gabriela Knaul. See 'UN independent expert concerned over reports of intimidation of judges in Sri Lanka' (UN News, 31 Dec 2012) $<$ https://news.un.org/en/story/2012/12/429212-un-independent-expert-concerned-over-reports-intimidationjudges-sri-lanka> accessed 2 Mar 2020.

46 See 11th special session of the Human Rights Council A/HRC/S-11/2(26 June 2009); Resolution 19/2 Promoting Reconciliation and Accountability in Sri Lanka A/HRC/RES/19/2 (3 April 2012); Resolution 22/1 Promoting Reconciliation and Accountability in Sri Lanka A/HRC/22/1 (9 April 2013); Resolution 25/1 
General, the resolutions of the Human Rights Council, the reports by the Office of the High Commissioner for Human Rights (OHCHR), and the report commissioned by the OHCHR represent the gradual ratcheting up of international pressure on the Sri Lankan Government to implement transitional justice measures. ${ }^{47}$ During this time, it was common for local and international debates on this topic to be infused with references to South Africa's experience of transitional justice. Distinct aspects of the South African transitional justice experience, such as its Truth and Reconciliation Commission, were invoked to call for similar interventions by the Sri Lankan Government. One of the responses of the Government to these international calls was the appointment of a presidential commission of inquiry - the Lessons Learnt and Reconciliation Commission. The report of this Commission was robust, except with regard to its findings on war crimes and crimes against humanity during the last stages of the internal armed conflict. ${ }^{48}$ The recommendations of the Commission, however, were not implemented effectively.. ${ }^{49}$

The invoking of South Africa's experiences in transitional justice in Sri Lanka was reinforced by the diplomatic engagements of South Africa with Sri Lanka. In 2014, the Deputy President of South Africa, Cyril Ramaphosa, was appointed as a Special Envoy of the President of South Africa to Sri Lanka. The Special Envoy visited Sri Lanka and met with key political and other stakeholders in the exercise of his mandate. In anticipation of his visit, the Special Envoy stated that 'We will discuss with the people in the community. We will also try to help the Sri Lankans with the Truth and Reconciliation process, their own constitutional reform and make sure Sri Lanka does indeed become a stable country where they will enjoy human rights. ${ }^{50}$ This observation points to the inter-related nature of transitional justice initiatives and constitutional reform in the South African experience. However, in invoking the South African experiences in Sri Lanka, the experiences in transitional justice and in constitutionmaking were invoked mostly as distinct experiences rather than as two sets of experiences that are inter-related.

Promoting Reconciliation and Accountability in Sri Lanka A/HRC/RES/25/1 (9 April 2014); 30/1 Promoting Reconciliation and Accountability in Sri Lanka A/HRC/RES/30/1 (14 October 2015).

47 The reports commissioned by the Secretary-General are the Report of the Secretary-General's Panel of Experts on Accountability in Sri Lanka (31 March 2011) and the Report of the Secretary-General's Internal Review Panel on United Nations Action in Sri Lanka (November 2012). The relevant reports by the UN Office of the High Commissioner for Human Rights (OHCHR) are: A/HRC/22/38 (11 February 2013); A/HRC/25/23 (24 February 2014); A/HRC/30/61 (28 September 2015); A/HRC/34/20 (10 February 2017); and A/HRC/37/23 (25 January 2018).

48 The Commission found that human rights violations such as enforced disappearances and extra-judicial killings were the acts of individual members of the armed forces and not in furtherance of a policy. See Report of the Commission of Inquiry on Lessons Learnt and Reconciliation (Nov 2011), para $4.282 \mathrm{ff}$ $<$ http://slembassyusa.org/downloads/LLRC-REPORT.pdf $>$ accessed 2 Mar 2020.

49 For a critical discussion on the implementation of the recommendations of the Commission of Inquiry on Lessons Learnt and Reconciliation see, Kristine Hoglund \& Camilla Orjuela, 'Friction over justice in postwar Sri Lanka', in Annika Björkdahl et al (eds), Peacebuilding and Friction: Global and Local Encounters in Post Conflict-Societies (Routledge 2016) 128 ff; Sharika Thiranagama, 'Claiming the State: Postwar Reconciliation in Sri Lanka' (2013) 4 Humanity 93, 98 ff. The recommendations of the Commission included resettlement of internally displaced persons and accountability for enforced disappearances.

50 See 'Working Visit by Deputy President Cyril Ramaphosa, appointed as Special Envoy of President Jacob Zuma to Sri Lanka, arrived on 7 July 2014' (South African High Commission Colombo, Sri Lanka) $<$ http://www.dirco.gov.za/colombo/newsandevents.html $>$ accessed 2 Mar 2020. 
The election of a new President and subsequently of a new parliament in Sri Lanka in 2015 brought with it the promise of legislative, policy, and constitutional reform. ${ }^{51}$ The agenda for constitutional reform involved an immediate amendment to the 1978 Constitution to reduce the powers of the Executive President, and the adoption of a new constitution within two years. A significant feature of the second stage of governance in post-war Sri Lanka (2015-2019) was extensive legislative and policy reform, and the attempt at constitutional reform. ${ }^{52}$ The South African experiences were invoked in discernible ways in several of these initiatives.

The Nineteenth Amendment to the 1978 Constitution was adopted in May 2015. The Amendment effected several changes, including the re-introduction of a modified Constitutional Council and the reduction of the powers of the Executive President. ${ }^{53}$ In January 2016, the Government formally introduced a procedure, by way of a motion in Parliament, for the adoption of a new constitution. ${ }^{54}$ This resolution mandated Parliament to convene as a Constitutional Assembly. Six thematic sub-committees were appointed under a Steering Committee of the Assembly for the purpose of making proposals. ${ }^{55} \mathrm{~A}$ panel of experts was appointed to support the work of the Constitutional Assembly. Meanwhile, a Public Representations Committee (PRC) was appointed by the Cabinet to receive proposals from the public with regard to constitutional reform. ${ }^{56}$ Once a draft constitution was adopted by the Constitutional Assembly, the draft was to be presented to Parliament through the Cabinet. From that point onward, the draft was to be adopted according to the procedure stipulated in the 1978 Constitution. ${ }^{57}$ The adoption of a new constitution requires approval by a special majority in Parliament and approval by the people at a referendum. ${ }^{58}$

Within four months of being appointed, the PRC visited all 25 districts in the island to receive submissions and submitted its report. ${ }^{59}$ Thereafter, the reports of the Sub-Committees of the Constitutional Assembly were published. This was followed by the submission of an Interim Report by the Steering Committee in October 2017. ${ }^{60}$ By this time, however, it was evident that the political will for constitutional reform was weakening. The constitutional crisis

51 For a discussion of these developments see Bhavani Fonseka et al, 'Two Years in Government: A Review of the Pledges Made in 2015 through the lens of Constitutional Reform, Governance and Transitional Justice' (Centre for Policy Alternatives, Feb 2017) < https://www.cpalanka.org/wp-content/uploads/2017/02/2February-2017-FINAL-REPORT-.pdf $>$ accessed 2 Mar 2020.

52 Notable among these reforms are the Right to Information Act (Act No 12 of 2016), the Office of the Missing Persons Act (Act No 14 of 2016), and the International Convention for the Protection of All Persons from Enforced Disappearance Act (Act No 5 of 2018).

53 For an analysis of the Nineteenth Amendment, see Asanga Welikala (eds), The Nineteenth Amendment to the Constitution: Content and Context (Centre for Policy Alternatives 2016).

54 Resolution adopted 9 March 2016 by the Eighth Parliament of Sri Lanka, as recorded in 2(243) Parliamentary Debates (Hansard) 212 ff.

55 Six sub-committees were appointed by the Constitutional Assembly on the following themes: fundamental rights, the judiciary, law and order, public finance, public service, and centre-periphery relations.

56 This Committee was appointed by the Cabinet of Ministers on 22 December 2015.

57 The 1978 Constitution, art 82.

58 ibid.

59 The report was submitted by 10 May 2016.

60 Interim Report of the Steering Committee of the Constitutional Assembly of Sri Lanka (21 Sep 2017) $<$ http://constitutionnet.org/sites/default/files/201709/Interim $\% 20$ Report $\% 20$ of $\% 20$ the $\% 20$ Steering $\% 20$ Commmittee $\% 20$ of $\% 20$ the $\% 20$ Constitutional $\% 20$ Ass embly\%20of\%20Sri\%20Lanka_21\%20September\%202017.pdf> accessed 2 Mar 2020. 
of October 2018 effectively meant that the constitutional reform process would not continue. This crisis began when the President purported to remove the Prime Minister and to appoint the former President (who was then an ordinary Member of Parliament) as the Prime Minister. This was followed by the prorogation and dissolution of Parliament. Matters were eventually resolved by December 2018, when a full bench of the Supreme Court held that the dissolution of Parliament by the President was unconstitutional.. ${ }^{61}$ In January 2019, the Expert Panel submitted its report and the Constitutional Assembly was convened to debate the report. This was the last formal development in the constitutional reform process. The tragedy of the Easter Sunday attacks in April 2019 brought to light the ongoing political rivalry between the President and the Prime Minister. ${ }^{62}$ A new president has been elected since then (in November 2019), signalling a change in the direction of governance. ${ }^{63}$ Parliamentary elections are due to be held in 2020, and elections to the Provincial Councils are overdue. ${ }^{64}$ The insecurities generated by the Easter Sunday attacks of 21 April 2019, ethnic polarization, and the desire for a strong government have been suggested as reasons for the change of government in November 2019.. ${ }^{65}$

During this second stage, the invoking of the South African experience of transition was evident at the level of national politics, in the public imagination, as well as in the normative debates among experts. ${ }^{66}$ Notable events during this time were the visits by Justices of the Constitutional Court - Justice Albie Sachs, Justice Dikgang Moseneke, and Justice Edwin Cameron to Sri Lanka. Another example is the visit by a South African delegation led by its Deputy Minister of International Relations and Cooperation. ${ }^{67}$ These visits involved

61 Subsequent to the Nineteenth Amendment, the President's power to dissolve Parliament could be exercised only after 4.5 years of the term of Parliament had elapsed: 1978 Constitution, art 70(1). This effectively meant that the President had no power to dissolve Parliament until March 2020. See Sampanthan v Attorney General SC (FR) 351-356, 358-361 of 2018, SC Minutes, 13 December 2018.

62 On 21 April 2019, six suicide bombers set off bombs in three churches and three hotels in Sri Lanka, leading to over 250 deaths.

63 The new President (the defence secretary up to 2014 and a brother of former President Mahinda Rajapakse) was nominated by a new party, the Sri Lankan Podujana Peramuna [Sri Lanka People's Front] (SLPP). This party was formed during the constitutional crisis. Soon after the election of the new President, the Prime Minister resigned and the former President Mahinda Rajapakse, was appointed as the new Prime Minister.

64 Nine provincial councils were established through the Thirteenth Amendment to the Constitution. This Amendment was enacted pursuant to the Indo-Lanka Accord signed between India and Sri Lanka, in which the Sri Lankan Government committed to constitutional reform for the devolution of power. The devolution of power was for the purpose of providing a political solution to the separatist demands by the Liberation Tigers of Tamil Eelam (LTTE). The Thirteenth Amendment has been criticised for failing to provide an effective solution to the ethnic conflict. See in this regard Rohan Edrisinha, 'Debating Federalism in Sri Lanka and Nepal', and Asanga Welikala, 'Constitutional Form and Reform in Postwar Sri Lanka: Towards a Plurinational Understanding', both in Mark Tushnet \& Madhav Khosla (eds), Unstable Constitutionalism: Law and Politics in South Asia (Cambridge University Press 2015) 291, 320.

65 Jayadeva Uyangoda, 'Sri Lanka's Presidential Election: Healing the Wounds in the New Task' (Groundviews, 19 Nov 2019) <https://groundviews.org/2019/11/19/sri-lankas-presidential-election-healing-the-wounds-isthe-new-task/> accessed 2 Mar 2020. On 21 April, five suicide bomb attacks were carried out in Colombo and one in Batticaloa resulting in more than 250 deaths. A local organization inspired by the Islamic State has been alleged to be responsible for the attacks, and investigations are ongoing.

66 See eg Kristine Höglund \& Camilla Orjuela, 'Friction and the pursuit of justice in post-war Sri Lanka' (2013) 1 Peacebuilding 300; Rachel Seoighe, 'Discourses of Victimization in Sri Lanka's Civil War: Collective Memory, Legitimacy and Agency’ (2016) 25 Social and Legal Studies 355.

67 Report on the Second Mandate of the Presidential Commission of Inquiry into Complaints of Abductions and Disappearances (the Paranagama Commission) (Aug 2015), 144 $<$ https://parliament.lk/uploads/documents/paperspresented/report-of-paranagama.pdf $>$ accessed 2 Mar 2020. 
knowledge exchange and sharing with lawyers, university students, and the public at large. The impact of the South African experience in Sri Lanka's public imagination was also evident in the public's submissions to the PRC and the Consultation Task Force on Reconciliation Mechanisms (the Task Force). The Task Force was appointed pursuant to a commitment made by the Government in the UN HRC resolution of 2015 to 'seek the views and comments of the public on the proposed mechanisms for transitional justice and reconciliation.' 68

The reports of the PRC and the Task Force refer to the South African experience in the 1990s. The PRC makes explicit references to the South African experiences in relation to the supremacy of the constitution, ${ }^{69}$ and the composition of the Judicial Service Commission. ${ }^{70}$ On the preferred model for 'truth seeking', it was noted by the Task Force that 'providing a space for affected persons and perpetrators to come forward to speak about their experiences and acknowledge past abuses was an important process in South Africa. ${ }^{71}$ The Task Force did demonstrate some sensitivity to the differences in the South African context. For instance it noted that the South African context was different 'in terms of the power relations between the majority and minority communities in each country.' ${ }^{72}$ The Task Force further noted a submission on the controversy regarding the granting of amnesty before the South African Truth and Reconciliation Commission. ${ }^{73}$ This observation is a useful reminder of the complex challenges that South Africa faced in its truth-telling and reconciliation process. The report also took note of the submission by filmmakers who requested that 'work on truth and justice' be supported 'by way of a fund or grant, such as in South Africa'.. ${ }^{74}$ Moreover, the report by the Presidential Commission of Inquiry into Complaints of Abductions and Disappearances also makes detailed references to the South African experience of truth-seeking. ${ }^{75}$

It is evident from the foregoing discussion that South African experiences were invoked with regard to transitional justice and constitutional reform in post-war Sri Lanka. However, it is also evident that the invocation was selective and focused on institutional design. This practice raises questions about methodology in the comparative enterprise, which I examine in the next section.

\section{CONSTITUTIONAL REFORM}

If there was any doubt about the political viability of the most recent constitutional reform proposals in Sri Lanka, the constitutional crisis of October 2018 made it clear that the initiative had failed. However, critical study of this crisis, in hindsight, provides useful insights on

68 Final Report of the Consultation Task Force on Reconciliation Mechanisms, vol 1 (17 Nov 2016), vii $<$ http://war-victims-map.org/wp-content/uploads/2017/02/CTF-Final-Report-Volume-I-Nov-16.pdf $>$ accessed 2 Mar 2020. The Task Force was appointed in January 2016.

69 Report on Public Representations on Constitutional Reform (May 2016), 28 (referring to the South African Constitution, art 2) <http://constitutionnet.org/sites/default/files/sri_lanka_prc_report-english-final.pdf $>$ accessed 2 Mar 2020.

70 ibid 151 (referring to the South African Constitution, art 178(1)).

71 Final Report of the Consultation Task Force on Reconciliation Mechanisms (n 68) 114.

72 ibid.

73 ibid 161.

74 ibid 337.

75 See Report on the Second Mandate of the Presidential Commission of Inquiry (n 67). This Commission was initially appointed in August 2013 and its mandate was extended in July 2014. 
constitutional reform - specifically in relation to Sri Lanka, but also more generally as a case study. In this section of the paper, I focus on three of these aspects, with the objective of critiquing the invocation of the South African experience of transformative constitutionalism in Sri Lanka's reform experiment. These three aspects are the process adopted for constitutional reform, public consultation, and certain substantive aspects of reform.

\section{A. Process}

The constitutional reform process in South Africa was unique and had an incremental character to it. Political negotiations resulted in an Interim Constitution, which provided specific procedures for the adoption of a new constitution. The substantive scope of the new constitution was determined by the Interim Constitution in the thirty-four principles that had been agreed upon.. ${ }^{76}$ This entire process was legitimized on multiple levels. The liberation movement and its long-drawn-out struggle legitimized the initial political negotiations and the adoption of an Interim Constitution. The first democratic elections of 1994 legitimized the Constitutional Assembly. The new constitution itself was legitimized by the Public Participation Programme and through review by the Constitutional Court. ${ }^{77}$ The Public Participation Programme attracted a very high degree of engagement, numerically as well as qualitatively. In its review of the draft constitution, the Constitutional Court received a further eighty-four submissions. ${ }^{78}$

The political and economic context of South Africa enabled the negotiators and key stakeholders to design this specific process for constitutional reform. ${ }^{79}$ The extended liberation struggle against apartheid generated the political, economic, and social momentum for this particular form of institutional transformation and for the multi-party consensus for the advent of constitutional democracy. International condemnation of apartheid had led to economic sanctions against South Africa and a pushback against South African sports teams in the global sporting arena.. ${ }^{80}$ The notion of 'transformation' was not only possible but necessary in this context. The processes adopted for constitution-making in South Africa were therefore inseparable from the design and substance of the new constitution. As the Constitutional Assembly observed, 'the essential principle of the constitution-making process from the outset [is] that the process of drafting and adopting the new constitution, is as important as the final product itself.' 81

The events that enabled the reform process to unfold in Sri Lanka were volatile because they took place in an unstable political environment. The appointment of a new President and the subsequent change of government in 2015 were the outcome of elections. These outcomes

76 See Interim Constitution of South Africa Act 200 of 1993 (as amended by Act No 2 of 1994 and Act No 3 of 1994), sch 4.

77 For a critical assessment of the public participation process in the South African constitution-making process, see Synnove Skjelten, A People's Constitution: Public Participation in the South African Constitution-making Process (Institute for Global Dialogue 2006).

78 ibid 140.

79 See eg Mervyn Bennun \& Malyn DD Newitt (eds), Negotiating Justice: A New Constitution for South Africa (University of Exeter Press 1995).

80 See eg Mark Orkin (ed), Sanctions Against Apartheid (Community Agency for Social Inquiry 1989).

81 Constitutional Assembly, 'Community Liaison Report' (Management Committee Document, Jun 1995), cited in Synnove Skjelten (n 77) 14. 
were made possible by a social movement, which emerged only in the few months prior to the presidential election. It was a movement of loosely convened groups, described as the 'January 8th movement', which had the immediate goal of election outcomes in view.. ${ }^{82}$ The name of the movement itself reflects the short-term and narrow goal of this movement. Elsewhere, this movement has been described as having a single-issue and common candidate focus.. ${ }^{83}$

During this time, there was a notable absence of agreement on the need for constitutional reform among the political parties and political representatives who supported the common candidate. ${ }^{84}$ The key actors in the move for constitutional reform were a handful of public representatives who either represented the minority Tamil political parties or the other smaller political parties. ${ }^{85}$

Wider Sri Lankan society was similarly 'unprepared', so to speak, for constitutional reform. ${ }^{86}$ Sri Lanka's three-decade-long internal armed conflict is evidence of the fractured nature of its society. Ethno-nationalism has been a strong organizing factor throughout Sri Lanka's post-independence history. ${ }^{87}$ The internal armed conflict was a result of a militant demand for a separate state by the LTTE. The internal armed conflict aggravated cleavages along ethnic lines within the state, and within wider society. The end of the internal armed conflict paved the way for the re-emergence of Sinhala-Buddhist nationalism. ${ }^{88}$ It has been argued that the re-emergence of Sinhala-Buddhist nationalism was a root cause of the antiMuslim riots of 2014 and 2018. ${ }^{89}$ The reactions to the Easter Sunday attacks in the form of anti-Muslim riots is further evidence of this phenomenon. Moreover, in Sri Lanka, several political parties are organized around ethnic and/or religious identity.. ${ }^{90}$

The absence of any sustained attempt at bridging the ethno-national divide is a notable gap in Sri Lanka's democracy. The divisive character of electoral politics is aggravated by social

82 See eg Asanga Welikala, 'The Sri Lankan Culture of Constitutional Law and Politics: The Lessons of the Constitutional Reform Exercise 2014-19 and the Constitutional Crisis of 2018', in Asanga Welikala (ed), Constitutional Reform and Crisis in Sri Lanka (Centre for Policy Alternatives 2019) 263.

83 For a critical discussion see Kumar David, 'Revisiting the Single-Issue Common-Candidate Strategy: Successes and Failures', in Asanga Welikala (ed), Constitutional Reform and Crisis in Sri Lanka (Centre for Policy Alternatives 2019) 89.

84 For an assessment of the political context at the time, see Fonseka et al (n 51) 5; Neil Devotta, 'A Win for Democracy in Sri Lanka' (2016) 27 Journal of Democracy 152; Thiranagama (n 49).

85 The two Members of Parliament (MPs) who led the process for constitutional reform were Dr Jayampathy Wickramaratne PC and MA Sumanthiran PC. MP Wickramaratne was nominated to Parliament by the United National Party (UNP) through the National List. MP Sumanthiran represents the Tamil National Alliance and was elected from Jaffna, the urban centre of the Northern Province of Sri Lanka. Both MPs are senior lawyers who entered the arena of representative politics in the last decade.

86 For an assessment of public perception, among others, of constitutional reform, see 'Opinion Poll on Constitutional Reform: Top Line Report' (Social Indicator, Centre for Policy Alternatives, Mar 2017) $<$ https://www.cpalanka.org/wp-content/uploads/2017/04/Rapid-survey final-report_March-2017.pdf $>$ accessed 25 Mar 2020.

87 See eg Kumari Jayawardena, 'Aspects of Class and Ethnic Consciousness in Sri Lanka' (1983) 14 Development and Change 1; Neil DeVotta, 'From Ethnic Outbidding to Ethnic Conflict: The Institutional Bases for Sri Lanka's Separatist War' (2005) 11 Nations and Nationalism 141.

88 See eg Mikael Gravers, 'Anti-Muslim Buddhist Nationalism in Burma and Sri Lanka: Religious Violence and Globalized Imaginaries of Endangered Identities' (2015) 16 Contemporary Buddhism 1.

89 See eg James John Stewart, 'Muslim-Buddhist Conflict in Contemporary Sri Lanka' (2014) 34 South Asia Research 241.

90 Examples include the Illankai Tamil Arasu Kachchi [Lanka Tamil State Party but commonly known in English as the Federal Party], the Sri Lanka Muslim Council and the Jathika Hela Urumaya [National Sinhala Heritage Party]. 
and cultural cleavages in Sri Lankan society. For instance, state-funded education is primarily in the 'mother tongue', resulting in students being divided into separate classrooms according to their first language. Historians and cultural studies specialists have pointed out that a particular notion of authenticity is evident in Sri Lankan society.. ${ }^{91}$ That notion is that Sri Lanka is the home of Sinhala-Buddhists, and that other ethnic or religious minorities are not 'authentic'. This frame of 'authenticity' is often applied to determine the 'insiders' and 'outsiders' within the other ethnic groups as well.. ${ }^{92}$ The demands for accountability for human rights violations, reparations, and reconciliation in relation to the internal armed conflict are a by-product of the more widespread problem of ethno-nationalism in Sri Lanka. In comparison, as Sparks points out, among the political parties in South Africa, only two were founded on ethnicity. ${ }^{93}$ Moreover, none of the ethnic groups were able to dominate the public sphere. ${ }^{94}$ It seems to me therefore that in South Africa, ethnicity does not carry the same significance that it carries in the Sri Lankan context.

The focus on constitutional reform in 2016 was largely in the absence of effective and sustained political, legal, and social responses to the divided characteristics of Sri Lankan society. The recommendations made by the Lessons Learnt and Reconciliation Commission and the recommendations made by the UN Human Rights Council had not been implemented in an effective manner by the Sri Lankan Government. Post-2015, the co-sponsored resolution adopted at the UN Human Rights Council was expected to set the agenda for transitional justice and reconciliation in Sri Lanka. ${ }^{95}$ The Sri Lankan Government implemented several of these recommendations. These included the establishment of the Office of Missing Persons, the return and resettlement of persons displaced by the internal armed-conflict, and the recommencement of investigations and prosecutions into several cases involving extra-judicial killings and enforced disappearances. However, these developments were criticised by some political representatives as well as segments of civil society as efforts to undermine Sri Lanka's 'sovereignty'.' 96

In South Africa, the democratisation of the 1990s included measures that accommodated the political interests of the majority as well as those of the minority. The 'white only' referendum and the Interim Constitution had the effect of addressing the insecurities of the minority regarding their political future in a democratic South Africa. The transition to democracy was a result of a long-drawn-out liberation struggle that had the support of the

91 For a helpful analysis, see Harshana Rambukwella, The Politics and Poetics of Authenticity (UCL Press 2018).

92 For a discussion see Pradeep Jeganathan \& Qadri Ismail (eds), Unmaking the Nation: The Politics of Identity \& History in Modern Sri Lanka (Social Scientists’ Association 1995).

93 The two exceptions are the Inkatha Freedom Party (IFP) and the Afrikaner People's Front. See Allister Sparks, Tomorrow is Another Country: The Inside Story of South Africa's Negotiated Revolution (Mandarin 1995) 230.

94 ibid.

95 Resolution 30/1 'Promoting reconciliation, accountability and human rights in Sri Lanka' A/HRC/RES/30/1 (1 October 2015).

96 See eg WA De Silva, 'Why Constitutional reform is a threat' Daily Mirror (6 Jan 2018) $<$ http://www.dailymirror.lk/article/Why-Constitutional-reform-is-a-threat-143484.html $>$ accessed 4 Feb 2020; Asoka Bandarage, 'Sovereignty, Territorial Integrity and Constitutional Reform in Sri Lanka' Daily Mirror (9 Oct 2017) $<$ http://www.dailymirror.lk/138037/Sovereignty-Territorial-Integrity-andConstitutional-Reform-in-Sri-Lanka $>$ accessed 4 Feb 2020. 
majority. Even then, the actual transition was gradual and took almost six years. ${ }^{97}$ The multiparty negotiation process, the Convention for a Democratic South Africa (CODESA) of the early 1990s was tense and challenging, even when the expectation was set at 'sufficient consensus'. ${ }^{98}$ The violence and unrest experienced during this time placed the negotiations under considerable pressure. ${ }^{99}$ In Sri Lanka, on the other hand, the anticipated transformation is perceived as being primarily for the recognition of the rights of the minorities. As was evident in public discussions regarding these proposals, the recognition of minority rights and powersharing arrangements are perceived as a threat to the majority. The attempt at forging a new constitution comes in the aftermath of a military victory in the armed struggle for separation, and the time-frame for the proposed project of constitutional reform was only two years. Moreover, political support for constitutional reform was fragile, and primarily driven by a few elected representatives. These stark differences in the political and social context suggest that the prospect of a South African style of 'transformation' was very low in Sri Lanka.

\section{B. Public Consultation and Participation}

The closed-door negotiation process that preceded the adoption of the Interim Constitution in South Africa was criticised for its lack of transparency and its failure to engage the public.. ${ }^{100}$ The adoption of the Interim Constitution, however, was followed by a public consultation process which has since then been acclaimed as a global model.

Similar to the constitution-making process, the South African process of public participation had a distinctive and incremental character to it. The consultation was framed by the thirty-four constitutional principles that had been agreed upon through a multi-party negotiation process. These principles indicated to the South African people the strength of the political commitment to the constitutional reform process. Moreover, the anticipated review of the draft constitution by the Constitutional Court was a guarantee to the people that these principles were in fact the foundation of the reform exercise. These normative aspects of the public consultation process were complemented well by the widespread public engagement processes implemented during this time.

The Public Participation Programme had a wide reach. The people's engagement with the process was dynamic. A campaign carrying the messages of 'You've made your mark, now have your say' and 'It's your right to decide your constitutional rights' was used to engage the public across radio, television, newspapers, and other forms of media.. ${ }^{101}$ The newsletter

97 For an account of the constitution-making process in South Africa, see Hassen Ebrahim, The Soul of a Nation: Constitution-making in South Africa (Oxford University Press 1998); Lauren Segal and Sharon Cott, One Law, One Nation: The Making of the South African Constitution (Jacana Media 2012).

98 Sparks (n 93) 133.

99 ibid.

100 See eg ibid 137 ff; Bennun \& Newitt (n 79).

101 Christina Murray, 'A Constitutional Beginning: Making South Africa's Final Constitution' (2001) 23 University of Arkansas at Little Rock Law Review 809, 816; Hassen Ebrahim \& Laurel E Miller, 'Creating the Birth Certificate of a New South Africa: Constitution Making after Apartheid', in Hassen Ebrahim \& Laurel E Miller (eds), Framing the State in Times of Transition: Case Studies in Constitution Making (United States Institute of Peace Press 2010) 134. 
Constitutional Talk, ${ }^{102}$ the Constitutional Education Programme, and constitutional public meetings were developed for the purpose of generating awareness among the 'rural, marginalised and disadvantaged communities' and to obtain their input. ${ }^{103}$ This was further complemented by strategic engagement with civil society through the National Sector Public Hearing Programme. In this programme, members of the Constitutional Assembly had direct engagement with civil society organizations on specific themes.. ${ }^{104}$ Submissions were received from the public at the first stage of the process (February to August 1995), and then on the working draft of the constitution as well, when this became available. ${ }^{105}$ This second stage of consultation continued until the adoption of the new constitution (November 1995 to February 1996). The submissions received from the constitutional public meetings for instance were transcribed, categorised, and directed to the relevant committees.

The process designed by the Constitutional Assembly extended to a post-adoption phase as well. ${ }^{106}$ In this phase, the Constitutional Assembly focused on education on the content of the adopted constitution.. ${ }^{107}$ The number of submissions received has been estimated at approximately 1.7 million and the total number of participants in the process at 3.8 million.. ${ }^{108}$ Approximately 1,200 civil society organizations were involved in the exercise.. ${ }^{109}$ It could perhaps even be said that the public debate generated by the process provided a healthy context for the work of the Constitutional Assembly. This was complemented by other initiatives taken at this time, such as the initiative to use 'plain language' in legal drafting as well as in drafting the new constitution.. ${ }^{110}$ The material developed by the Constitutional Assembly was produced in this style and translated into the 11 official languages.. ${ }^{111}$

Nevertheless, questions have been raised by some as to the impact of the submissions and consultations on the drafting of the new constitution.. ${ }^{112}$ Even the sceptics concede, however, that the public participation process and programmes were inclusive, that they generated awareness about constitutional governance, and that they earned widespread legitimacy for the reform exercise. ${ }^{113}$

The Sri Lankan public consultation process was procedurally and qualitatively different from that of the South African process. The Public Representations Committee was appointed by the Cabinet in January 2016 and given four months to submit its report. Twenty themes

102 Skjelten (n 77) 86-87.

103 ibid 76. On constitutional public meetings, see ibid $56 \mathrm{ff}$.

104 ibid 104 ff. The sectors were: judiciary and legal systems, business, children's rights, traditional authorities, religious groups, youth, labour, women, national machinery and the advancement of women, local government, socio-economic rights, and land rights.

105 Ebrahim \& Miller (n 101).

106 ibid 148.

107 ibid 138 .

108 ibid 159. See also generally South Africa History Online, 'Chapter 13 - The public participation process' (1 Sep 2019) <https://www.sahistory.org.za/archive/chapter-13-public-participation-process> accessed 2 Mar 2020.

109 Ebrahim \& Miller (n 101) 111.

110 For a discussion of this initiative, see ibid $91 \mathrm{ff}$.

111 ibid 93.

112 Siri Gloppen, South Africa: The Battle over the Constitution (Ashgate 1997).

113 See eg Alexander Edward Hudson, The Impact of Public Participation in Constitution Making (PhD dissertation, University of Texas at Austin 2018) $46 \mathrm{ff}$. 
were listed on which the PRC called for submissions.. ${ }^{114}$ The PRC did not have a mandate to educate the public on constitutional reform. Although the Committee did not have the luxury of time, they travelled to all twenty-five districts in the country.. ${ }^{115}$ It was the first time in Sri Lanka that public consultation was carried out at the level of all the districts. The Committee's report was submitted by the end of April 2016.

The public representations were carried out within a loose framework. The list of themes was open-ended, allowing persons coming before the PRC to make a wide range of submissions. The broad nature of the themes, along with the lack of strong political support for the public consultation process, diluted the process to some degree. The public consultation process was primarily a method of collecting submissions. No public education programmes were implemented during this time to engage the public or to provide them with required information for consideration in making their submissions. The short time period for the mandate of the PRC minimized the possibility of mobilizing the public around the idea of constitutional reform. It further placed the PRC under pressure in terms of producing their report. In total, over 4,200 submissions were received by the PRC.. ${ }^{116}$

The lack of time, the absence of strong political support, and the lack of active public awareness-raising and dialogue contributed to the low level of engagement by the people with the PRC. During the same time, some segments of the Buddhist clergy and Opposition Members of Parliament were critical of the public consultation process as well as of the attempt at constitutional reform. These related factors undermined the legitimacy of the public consultation process in Sri Lanka.

\section{Substantive Aspects of Constitutional Law}

The South African experiences in constitutional reform and the notion of transformative constitutionalism were invoked in Sri Lanka in relation to substantive reform proposals as well. The proposals for a Constitutional Court and for the judicial enforcement of economic and social rights (ESRs) in the constitutional reform process in Sri Lanka were inspired by the South African experience. ${ }^{117}$ In the somewhat marginal public debates on the proposed reforms, proponents of a Constitutional Court made regular and routine reference to the structure of the Constitutional Court of South Africa, as well as to its jurisprudence on the

114 The themes were - nature of the state, form of government, basic structure of the constitution, fundamental rights and directive principles of state policy, legislature, supremacy of constitution or parliament, separation of powers, independence of the judiciary and the court structure, constitutional court, devolution and local government, sharing of power at the centre, constitutional council and independent commissions, public service, electoral reforms, judicial review of legislation, powers of president under parliamentary system, election of president under parliamentary system, public security, finance, and any other issues. See Report on Public Representations on Constitutional Reform (n 69) 211.

115 Report on Public Representations on Constitutional Reform (n 69) iii.

116 ibid vii.

117 For a detailed analysis of these proposals, see Mario Gomez et al, 'Constitutionalising Economic and Social Rights in Sri Lanka' (CPA Working Papers on Constitutional Reform No 7, Sep 2016) $<$ https://www.cpalanka.org/wp-content/uploads/2016/09/Working-Paper-7.pdf $>$ accessed 2 Mar 2020; Tom G Daly, 'A Constitutional Court for Sri Lanka? Perceptions, Potential and Pitfalls' (CPA Working Papers on Constitutional Reform No 15, Apr 2017) $<$ http://constitutionalreforms.org/wpcontent/uploads/2016/06/CPA_WP_CR_No_15 Final-TDrevno-tracks.pdf > accessed 2 Mar 2020. 
enforcement of ESRs.. ${ }^{118}$ The idea was however met with some criticism in Sri Lanka. It was argued that a new court that is above the Supreme Court and comprised of judges who are direct appointees would undermine the standing of the judiciary.. ${ }^{119}$ The proposal for judicial enforcement of ESRs was subject to criticism as well. One common argument was to point to the inequalities in South African society as evidence that judicially enforceable ESRs guarantees have lacked impact. ${ }^{120}$ However, in the submissions made to the PRC, by and large the proposals for judicial enforcement of ESRs received considerable support, resulting in the PRC recommending them.- ${ }^{121}$

The pushback and the notable lack of support for these proposals among the members of the Constitutional Assembly and wider Sri Lankan society can be partly explained as follows. In South Africa, the establishment of a Constitutional Court was central to the establishment of a new genre of constitutionalism. The exercise of public power and even certain forms of private relationships are subject to review for their constitutionality by the Constitutional Court. Within this institutional framework, judicially enforceable ESRs are specific constitutional guarantees that could be relied upon to address the inequalities of South African society. The models of constitutional courts and judicially enforceable ESRs have been adopted in different constitutions globally.. ${ }^{122}$ However, these institutional models carry more depth and relevance when understood within the broader constitutional shift at play. It was difficult to identify a similar ideological or normative commitment in the Sri Lankan constitutional reform exercise. Consequently, advocacy for the establishment of a constitutional court and for judicial enforceability of ESRs did not attract support among the political elite or the general public. This was compounded by three other factors. One was the open-ended nature of the process for constitutional reform. The second was the absence of a public education programme on the constitutional reform project. The third was the brief public consultation process.

\section{No Fundamental Shift}

The Sri Lankan constitutional reform experiment was notable in that it did not aim to achieve a fundamental shift through a new constitution in an explicit way. It was understood that several contentious aspects of the current 1978 Constitution would not be reformed. These contentious aspects include the 'foremost' place given to Buddhism,. ${ }^{123}$ the protection of personal laws from judicial review,.. ${ }^{124}$ and the continuation of power-sharing in terms of devolution as

${ }^{118}$ See eg 'Introduction', in Report of the Sub-Committee on Fundamental Rights (Steering Committee of the

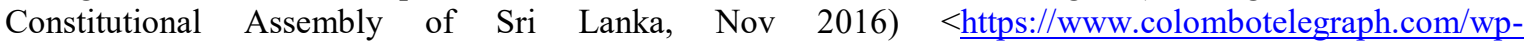
content/uploads/2016/11/01-Fundamental-Rights-ste-1.pdf $>$ accessed 4 Feb 2020.

119 See in this regard CA Chandraprema, 'Radical changes in the Judiciary: New draft constitution - part 4' The Island (7 Aug 2018) <http://www.island.lk/index.php?page_cat=article-details\&page=articledetails\&code_title=189224> accessed 2 Mar 2020.

120 Discussions at the public meeting organized by the Sri Lanka Bar Association on 'The Report of the SubCommittee of the Constitutional assembly on Fundamental Rights - perspectives on the inclusion of SocioEconomic Rights in the new constitution', 10 Jan 2017.

121 Report of the Public Representations Committee (n 69) $100 \mathrm{ff}$.

122 See eg the Constitution of Nepal 2015 and the Constitution of Kenya 2010.

1231978 Constitution, art 9.

124 ibid art 16. 
opposed to the introduction of federalism.. ${ }^{125}$ The constitutional reform agenda was modest and was aimed at improving the existing arrangements for devolution of power, improving the constitutional approach to the 'nature of the state', the re-introduction of parliamentary form of government, the establishment of a second chamber, the establishment of a constitutional court, and electoral reform.. ${ }^{126}$ The particular form of republican constitutional governance already in place under the 1978 Constitution was therefore to continue in some form alongside anticipated reform. In the absence of political will for a fundamental shift in constitutional governance, Sri Lanka's use of the South African experiences did not carry with it the promise of transformative constitutionalism.

Having analysed the selective and disconnected invocation of the South African experience in Sri Lanka's reform process, in the next part, I discuss the implications of this experience for the comparative enterprise.

\section{SPECIFICITY, CONSTITUTION-MAKING, AND THE COMPARATIVE ENTERPRISE}

In Parts III and IV, I argued that the attempts at emulating South Africa's experience of transformative constitutionalism in Sri Lanka have not been effective. I offered two explanations for this failure. One relates to the nature of transformative constitutionalism itself. Transformative constitutionalism is not merely a question of constitutional design. Rather, it is constitutional design that takes place according to an incremental process, which is in turn enabled and sustained by a specific political and social context. The literature on transformative constitutionalism focuses primarily on the role of the Constitutional Court. However, I argued in Part II that the process followed in constitutional reform and other aspects of constitutional governance are also significant aspects of transformative constitutionalism. The other, related explanation is the contrast in the Sri Lankan context, in which the South African experiences were invoked. This contrast is evident in almost all comparable aspects such as the political, social, economic, and demographic aspects. In this part, I develop these explanations further in an attempt to affirm existing knowledge on comparative methodology in constitution-making. I argue that these experiences demand more caution, attention to detail, and sensitivity to context in the use of comparative methods in constitution-making.

Emulating the South African experience of transformative constitutionalism demands that due attention be paid to its organic nature. The historical context, including the liberation movement, shaped the material conditions under which democratization and innovation in constitutional governance were made possible. The possibility of democratic constitutional governance was made sustainable through the incremental process adopted, the public consultation process, as well as the substantive aspects of the proposed constitution.

Foregrounding the organic and specific nature of constitutional reform in South Africa raises questions about whether comparative methods have any relevance, particularly in the field of constitution-making. It seems to me however that paying attention to the specificity of a given experience in constitution-making in fact advances and strengthens the comparative

125 See Interim Report of the Steering Committee (n 60) Part IV.

126 See generally ibid. 
enterprise. I can identify at least three advantages to paying attention to the organic nature and specificity of constitution-making.

Firstly, it allows for a more honest use of comparative method in constitution-making. It compels constitutional legislators to admit to what may be possible or impossible in their own context. It demands a deeper assessment of the work that is required in the attempt to emulate comparative experiences. Therefore, secondly, it allows for setting more realistic expectations from the constitutional reform exercise. The study of the organic nature of a given constitutional reform experience can lead to a better understanding of the conditions that facilitated that process. Being conscious of whether these conditions are available in their own context or not would allow constitutional legislators to be more realistic in setting their expectations for constitutional reform. Thirdly, sensitivity to the organic nature and specificity of the constitution-making process is useful in identifying practical steps that are necessary in emulating that comparative experience. It is helpful in designing processes, including in sequencing. It is also helpful in institutional design.

In examining the invocation of the South African experience in Sri Lanka's most recent constitution-making exercise, I am, in fact, repeating the call against the superficial importation of institutional models within the comparative enterprise. ${ }^{127}$ A deeper and contextual understanding of the South African experience alerts the constitutional legislator to what I view as the more useful and interesting lessons that can be learnt from South Africa from a comparative perspective. I identify and discuss four such lessons below.

Firstly, the South African constitutional reform experience was a definitive departure not only from its apartheid past, but also from liberal constitutionalism as it is broadly understood. The result was a new genre of constitutionalism. The defining characteristics of this genre include the following: (1) a clear vision of social welfare that demands distributive justice from the state, including from the judiciary; (2) measures for transitional justice such as truth-telling, reparations and amnesty, and the restructuring of legal and social institutions; and (3) the conscious and deliberate public engagement and consultation in the process. The work of the Truth and Reconciliation Commission created the social and cultural ethos within which South African society was prepared for the process of replacing a society based on apartheid with what has been described as 'a rainbow nation'... ${ }^{128}$ Within this context, constitutional reform is evidently an outcome of the struggle for liberation. It undeniably has revolutionary and radical undertones to its approach. This is the approach described as 'post-liberal' by Klare.. ${ }^{129}$

A high degree of consistency with this vision of constitutional reform was evident in the general South African experience of transition to democracy. That is the second lesson to be learnt. The greater the coherence across the process, public engagement, institutional design, and the substantive constitutional guarantees, the greater the likelihood that the vision would be embraced across society. South Africa's transformation was in the interests of the majority,

\footnotetext{
127 See eg Pierre Legrand, 'The Impossibility of Legal Transplants' (1997) 4 Maastricht Journal of European and Comparative Law 111.

128 'We enter into a covenant that we shall build a society in which all South Africans, both black and white will be able to walk tall, without any fear in their hearts, assured of their inalienable right to human dignity - a rainbow nation at peace with itself and the world': President Nelson Mandela at his inauguration speech, as cited in Sparks (n 93) 229.

129 Klare (n 16) 150.
} 
and it took place at a time when a new wave of democratization was taking place globally.. ${ }^{130}$ In Sri Lanka, on the other hand, not only was the anticipated transformation perceived as being in the interest of minorities, but it also unfolded within a global context of the rise of populism. ${ }^{131}$ These additional challenges in Sri Lanka limit the relevance of the South African experience to Sri Lanka's attempts at constitutional reform.

The third useful lesson from South Africa regarding constitution-making, from a comparative perspective, is that the buy-in of powerful political elites and the different groups and communities should ideally be a pre-condition. In the case of South Africa, the Interim Constitution and the constitutional principles reflected a multi-party commitment. That brought a measure of clarity and a political vision to the task of constitutional reform. In Sri Lanka, the buy-in of political elites across party lines was lacking. Moreover, it was unclear as to whether the reform process had the support, by and large, across Sri Lanka's diverse ethnic and religious communities.

The fourth lesson from the South African experience is with regard to public engagement and education. There is not much evidence as to the input to the constitutional reform process by the public via the public consultation process. However, the Public Participation Programme generated public engagement and debate on numerous issues related to the reform exercise in South Africa. This facilitated public support and ownership of the reform project. In Sri Lanka, the public consultation process was primarily for receiving submissions from the public and was brief. By design, the process was severely limited and could not therefore generate a sense of public support or ownership of the reform project.

\section{CONCLUSION}

Writing in 1985, Frankenberg warned that 'As long as foreign places only look like or unlike home ... and as long as they are treated as same or other, they do not speak for themselves. ${ }^{132}$ In this article, I argued that the South African experiences in constitutional reform were invoked in Sri Lanka's most recent constitutional reform exercise in a way that did not allow the South African experiences to 'speak for themselves'. Inspired primarily by Frankenberg's proposal for a layered approach to comparative constitutional law, I have attempted to allow the South African experience in transformative constitutionalism to speak for itself. Based on that, I explained why I take the view that Sri Lanka's reliance on the South African experiences could have benefitted from a closer reading of the South African experience. In doing so, I have further argued that transformative constitutionalism is a much broader playing field and includes constitution-making. Transformative constitutionalism, as a genre, therefore is likely to be most meaningful if it travels and inspires in that broader sense rather than in terms of a bundle of institutions or as piecemeal substantive guarantees.

\footnotetext{
130 See in this regard Samuel P Huntington, 'Democracy's Third Wave' (1991) 2 Journal of Democracy 12.

131 See eg Benjamin Moffitt, The Global Rise of Populism: Performance, Political Style, and Representation (Stanford University Press 2016).

132 See Gunter Frankenberg, 'Critical Comparisons: Re-thinking Comparative Law' (n 14).
} 


\section{University Library}

\section{- M M I N E R VA A gateway to Melbourne's research publications}

Minerva Access is the Institutional Repository of The University of Melbourne

Author/s:

Samararatne, D

Title:

From South Africa to Sri Lanka: Prospects of Travel for 'Transformative Constitutionalism'

Date:

2020

Citation:

Samararatne, D. (2020). From South Africa to Sri Lanka: Prospects of Travel for

'Transformative Constitutionalism'. Asian Journal of Comparative Law, 15 (1), pp.45-68. https://doi.org/10.1017/asjcl.2020.4.

Persistent Link:

http://hdl.handle.net/11343/241708 